\title{
Expression of Natural Cytotoxicity Receptors on and Intracellular Cytokine Production by NK Cells in Women with Gestational Diabetes Mellitus
}

（妊娠糖尿病における末梢血 NK 細胞 NCR 発現と 細胞内サイトカイン産生に関する研究)

弘前大学大学院医学研究科成育科学領域 周産期医学教育研究分野 氏名 千葉仁美 


\section{Introduction}

NK cells are the major lymphocytes in the uterus during early pregnancy. ${ }^{1}$ The number of uterine NK cells increases during the late secretory phase of the menstrual cycle and increases rapidly during early pregnancy. ${ }^{2,3} \mathrm{NK}$ cells are important for the regulation of extravillous trophoblast cell invasion and spiral artery remodeling in the pregnant decidua. ${ }^{4-7}$ Maximum extravillous trophoblast cell invasion occurs during the first trimester of gestation, peaking at around 10-12 weeks. ${ }^{8-10}$ NK cells with abnormal expression of surface receptors and cytokine production have been reported to be related with reproductive failure such as infertility, implantation failures, recurrent pregnancy loss, and preeclampsia (PE). ${ }^{11-15}$ Therefore, the function of NK cell and pregnancy are strongly correlated with each other.

Gestational diabetes mellitus (GDM) is characterized by glucose intolerance that is caused by metabolic changes during pregnancy, and is considered a risk factor for the occurrence of DM in future. There are studies that reported changes in the cytokine in women with GDM. The concentration of serum IFN- $\gamma$ and adiponectin decreased, while serum leptin, IL-6, IL-10, and TNF- $\alpha$ increased in GDM women when compared to that in healthy pregnant women. ${ }^{16}{ }^{17}$ Placenta and adipose tissues from patients with GDM released higher amounts of TNF- $\alpha$ in response to high glucose than that from normal pregnant women. ${ }^{18}$ Plasma TNF- $\alpha$ were reported to be low during the first and second trimester, but it increased during late pregnancy, and was inversely correlated with the insulin sensitivity. ${ }^{19,20}$

However, the relationship between GDM and the functions of NK cells in pregnant women has not been clarified so far. The purpose of this study was to evaluate the expression of peripheral blood NK (pNK) cell surface markers (CD16, NKp46, and NKp30) and the percentage of cytokine (IFN- $\gamma$, TNF- $\alpha$, TGF- $\beta$, and VEGF) producing pNK cells in women with / without GDM at 12 weeks of pregnancy. 


\section{Materials and Methods}

\section{Study Subjects}

We designed a prospective study and patients from Hirosaki University Hospital were recruited for this study between July 2014 and March 2015. This study was approved by the local ethics committee, and signed informed consent forms were obtained from all study subjects. Blood samples were collected during routine blood tests for prenatal check-up at 12 weeks of gestation.

Thirty-four Japanese women (GDM (n=7), non-GDM (n=27)) with singleton pregnancy were included. All GDM patients were diagnosed at 12 to 16 weeks of gestation. Pregnant women with multi-fetal gestations, pre-gestational diabetes, and overt diabetes were excluded, while pregnant women with impaired glucose tolerance before the onset of pregnancy were included in this study. Maternal and neonatal characteristics are shown in Table 1. Two-hour-glucose level of 75-g OGTT in GDM group was significantly higher than that in the non-GDM group. There were no complications reported in the newborn infants (such as macrosomia, shoulder dystocia, and hypoglycemia) in both the GDM and non-GDM groups and there were no pregnant women suffering from PE in both the GDM and non-GDM groups.

\section{Screening of GDM}

All pregnant women were subjected to a two-step screening method for GDM. This screening method is based on the Guideline for Obstetrical Practice in Japan 2014. ${ }^{21}$ Briefly, women who had a random plasma glucose level of $\geq 95 \mathrm{mg} / \mathrm{dl}$ at 12 weeks of gestation were subjected to $75-\mathrm{g}$ OGTT after fasting overnight. Diagnosis of GDM was based on the criteria of one or more abnormal values [fasting $\geq 92 \mathrm{mg} / \mathrm{dl}(5.1 \mathrm{mmol} / \mathrm{l})$, such as 1 hour $\geq 180 \mathrm{mg} / \mathrm{dl}(10.0 \mathrm{mmol} / \mathrm{l})$ or 2 hour $\geq 153 \mathrm{mg} / \mathrm{dl}(8.5 \mathrm{mmol} / \mathrm{l})]$ reported for the subjects. Pregnant women, not diagnosed as GDM at 12 weeks of screening, were again subjected to random blood glucose measurement at 
28 weeks of gestation. Women with random plasma glucose $\geq 100 \mathrm{mg} / \mathrm{dl}$ were subjected to $75-\mathrm{g}$ OGTT (the same GDM criteria).

GDM screening method in Japan was modified by the International Association of Diabetes and Pregnancy Study Groups (IADPSG) recommendations. ${ }^{22}$ For GDM screening, IADPSG recommends the measurement of fasting plasma glucose (FPG), HbA1c, or random plasma glucose in all or only high-risk women during the first prenatal visit and to perform 75-g OGTT at 24-28 weeks of gestation after overnight fasting. This test has been suggested for all women not previously diagnosed with overt diabetes or GDM in earlier tests. ${ }^{22}$ The cut-off value for random plasma glucose level has not been determined, however a random plasma glucose level of $\geq 95 \mathrm{mg} / \mathrm{dl}$ at 12 weeks of gestation and $\geq 100 \mathrm{mg} / \mathrm{dl}$ at 28 weeks of gestation are easier and more cost-effective for GDM screening in multi-organizations studies conducted in Japan (unpublished data). Therefore, in the Guidelines for Obstetrical Practice in Japan 2014, a random plasma glucose of $\geq 95 \mathrm{mg} / \mathrm{dl}$ at 12 weeks of gestation and $\geq 100 \mathrm{mg} / \mathrm{dl}$ at 28 weeks of gestation are recommended as cut-off values for GDM screening. ${ }^{21}$ In our study, all GDM women were diagnosed between 12 to 16 weeks of gestation. Based on the IADPSG criteria, the total incidence of GDM was $17.8 \%{ }^{22}$ On the other hand, the percentage of GDM in our study was $20.5 \%$ ( 7 women with GDM in 34 pregnant women).

\section{Expression of NK cell surface receptors}

Peripheral blood mononuclear cells (PBMCs) were isolated from heparinized whole blood using a Histopaque ${ }^{\circledR}-1077$ (Sigma-Aldrich, Co., St Louis, MO, USA). Isolated mononuclear cells were washed twice with phosphate-buffered saline solution (PBS), and adjusted to $5 \times 10^{6}$ cells / $\mathrm{ml}$.

Using 100 $\mu$ l of PBMCs, we evaluated the expression of pNK cell surface markers. For the NK cell labeling, monoclonal antibodies (mAbs) were used. The combinations of antibodies 
were as follows; CD56 phycoerythrin (PE) (Beckman Coulter, Inc., Brea, CA, USA) / CD16 fluorescein isothiocyanate (FITC) (BD, Franklin Lakes, NJ, USA), CD56 FITC (BD) / NKp46 PE (Beckman Coulter), and CD56 FITC / NKp30 PE (Beckman Coulter). The cells were incubated in dark with mAbs for 15 minutes at room temperature. Then cells were washed twice in PBS, lysed and fixed. Two more washes were carried out with PBS. Finally, immunofluorescence and multicolor flow cytometric analysis were performed using a FACSCanto flow cytometer (Beckton Dickinson, Son Jose, CA, USA) with computer interfacing to BD FACSDiva for full-list-mode data storage, recovery, and analysis. The gate was set on the lymphocyte region by characteristic forward and side scatter parameters. For each sample, $3 \times 10^{4}$ peripheral blood lymphocytes were evaluated.

\section{Expression of intracellular cytokine production by NK cells}

PBMCs were stimulated with phorbol 12-myristate 13-acetate (PMA) (25ng / ml) and ionomysin $(1 \mu \mathrm{mol} / \mathrm{l})$ in the presence of brefeldin $\mathrm{A}(10 \mu \mathrm{g} / \mathrm{ml})$ for 4 hours at $37^{\circ} \mathrm{C}$ in a $5 \%$ $\mathrm{CO}_{2}$ humidified incubator, after washing. These cells were stained for 15 minutes at room temperature in the dark with CD56 FITC or CD56 Phycoerythrincyanin 5.1 (PC5) (Beckman Coulter) and washed twice with PBS. Next, $200 \mu \mathrm{L}$ of Cytofix/Cytoperm ${ }^{\circledR}(\mathrm{BD})$ were added to the stimulated cells and washed twice with the Perm/Wash Buffer (BD). After fixation and permeabilization, the cells were incubated for 30 minutes in the dark with IFN- $\gamma$ FITC (Beckman Coulter), TNF- $\alpha$ PE (Beckman Coulter), and TGF- $\beta$ allophycocyanin (APC) (R\&D systems, Inc., Minneapolis, MN, USA). Appropriate isotype controls were used for each antibody. Cells were washed twice in Perm/Wash Buffer and resuspended in $250 \mu \mathrm{L}$ of PBS for subsequent flow cytometric analysis. Intracellular VEGF (R\&D systems) expression was also evaluated using methods similar to that of the cytokine staining without stimulation in PMA, ionomysin, and brefeldin A. 
Immunofluorescence and multicolor flow cytometric analysis were performed using FACSCanto flow cytometer (Beckton Dickinson, Son Jose, CA, USA) with computer interfacing to BD FACSDiva for full-list-mode data storage, recovery, and analysis. The gate was set on the lymphocyte region by characteristic forward and side scatter parameters. For each sample, $3 \times 10^{4}$ peripheral blood lymphocytes were evaluated

\section{Statistical Analysis}

Patient characteristics were presented as means \pm SD, and laboratory data were presented as median (interquartile range). Age, BMI, gestational age at delivery, and birth weight were analyzed by Student's t-test, and a family history of diabetes mellitus were analyzed by $\chi^{2}$-test. Statistical differences between GDM and non-GDM groups were evaluated using Mann-Whitney U non-parametric analysis. Differences were considered significant for a probability of $<0.05$. All statistical analysis were performed using SPSS version 22.0 (IBM, Chicago, IL, USA).

\section{Results}

\section{Expression of surface receptors on pNK cells in pregnant women with/without GDM}

Representative dot plots of the expression of NK cell surface receptors such as CD16 and natural cytotoxicity receptors (NKp46 and NKp30) on pNK cells for pregnant woman with GDM and pregnant woman without GDM is shown in Fig.1. The percentage of CD56 ${ }^{\mathrm{dim}} / \mathrm{CD} 16^{+}$ NK cells in GDM group [77.81\% (56.67-86.31), Median (interquartile range)] was higher than that in the non-GDM group [58.94\% (51.96-72.00)] (Fig. 2 (A)), however the difference was not significant. The percentage of CD56 $6^{\text {bright }} / C^{2} 16^{-}$NKcells in GDM group [1.86\% (1.06-3.02)] was significantly lower than that in the non-GDM group [3.39\% (2.20-4.58), $\mathrm{p}<0.05$ ] (Fig. 2 (B)). The percentage of $\mathrm{CD} 56^{+} / \mathrm{NKp} 46^{+} \mathrm{NK}$ cells was not different between the GDM and 
non-GDM group. Further analysis of the CD56 fluorescence intensity revealed that the percentage of $\mathrm{CD} 56^{\text {bright }} / \mathrm{NKp} 46^{+} \mathrm{NK}$ cells in the GDM group [2.57\% (2.00-2.77)] was significantly lower than that in the non-GDM group [5.98\% (5.20-9.14), p<0.05] (Fig. 2 (C)). There was no significant difference in the expression of NKp30 between the two groups.

\section{Cytokines Production by pNK Cells in pregnant women with/without GDM}

Representative dot plots for the percentage of cytokine (IFN- $\gamma$, TNF- $\alpha$, TGF- $\beta$ and VEGF) producing NK cells and NK cell subpopulation in pregnant woman with GDM and without GDM is shown in Fig. 3. NK cells were double stained for IFN- $\gamma$ and TNF- $\alpha$. We classified NK cells as IFN- $\gamma^{+} / \mathrm{TNF}-\alpha$, IFN- $\gamma^{-} / \mathrm{TNF}-\alpha^{+}$, IFN $-\gamma^{+} / \mathrm{TNF}-\alpha^{+}$, and IFN- $\gamma^{-} / \mathrm{TNF}-\alpha^{-} \mathrm{NK}$ cells. The percentage of IFN- $\gamma$ producing NK cells (the sum of $\mathrm{CD} 56^{+} / \mathrm{IFN}-\gamma^{+} / \mathrm{TNF}-\alpha^{-}$and $\mathrm{CD} 56^{+} / \mathrm{IFN}-\gamma^{+} / \mathrm{TNF}-\alpha^{+}$cells) was significantly higher in the GDM group $[73.90 \%$ (68.46-78.95)] than that in the non-GDM group [53.14\% (11.80-68.88), $\mathrm{p}<0.05]$ (Fig. 4 (A)). The percentage of TNF- $\alpha$ producing NK cells (the sum of $\mathrm{CD} 56^{+} / \mathrm{IFN}-\gamma^{-} / \mathrm{TNF}-\alpha^{+}$and $\mathrm{CD}^{2} 6^{+} / \mathrm{IFN}-\gamma^{+} / \mathrm{TNF}-\alpha^{+}$cells) was significantly higher in the GDM group $[59.91 \%$ (52.90-70.24)] than that in the non-GDM group [42.98\% (18.20-60.77), $\mathrm{p}<0.05]$ (Fig. 4 (B)). The percentage of both IFN- $\gamma$ and TNF- $\alpha$ producing NK cells (CD56 ${ }^{+} / \mathrm{IFN}-\gamma^{+} / \mathrm{TNF}-\alpha^{+}$cells) was significantly higher in the GDM group [54.74\% (48.29-64.71)] than that in the non-GDM group [37.41\% (8.22-53.92), $\mathrm{p}<0.05]$ (Fig. 4 (C)). On the other hand, the percentage of TGF- $\beta$ producing $\mathrm{CD}^{+} 6^{+}$cells was significantly lower in the GDM group [3.28\% (2.68-5.98)] than that in the non-GDM group [12.92\%(6.19-37.59), $\mathrm{p}<.05]$ (Fig4 (D)). Similarly, the percentage of VEGF producing CD56 $6^{\text {bright }}$ cells was also significantly lower in the GDM group [1.46\%(1.29-1.51)] than that in the non-GDM group [3.88\%(2.99-6.31), $\mathrm{p}<0.05]$ (Fig. 4 (E)).

\section{Discussion}


GDM is characterized by hyperglycemia during pregnancy. Women with GDM have a high risk of type $2 \mathrm{DM}$ in future than the women with normal glucose tolerance during pregnancy. ${ }^{23}{ }^{24}$ It was reported that women diagnosed as GDM have islet cell antibodies. ${ }^{25,26}$ Whether positive islet cell antibodies can predict type 1 diabetes in future is debatable. ${ }^{26} 27$ However, it is obvious that GDM women have a risk of DM in future.

The etiology of DM is associated with multiple factors such as genetic factors, diet, obesity ,and reduced exercise. ${ }^{28}$ Immunological abnormalities such as abnormal expression of NK cell surface markers and abnormal cytokine production may also be associated with the pathogenesis of DM. In fact, some researchers had reported decreased expression of NKp46 and changed levels of serum cytokines such as IFN- $\gamma$, TNF- $\alpha$, TGF- $\beta$, and VEGF in DM patients. ${ }^{29-47}$ Recently, the relationship between immune response and metabolic diseases such as obesity, type 2 diabetes, and GDM was reported. ${ }^{48}$

In type $1 \mathrm{DM}$, circulating peripheral blood NK cells play an immunoregulatory role. ${ }^{34,38} \mathrm{NK}$ cells were not only capable of killing islet cells, but also seemed to be important in the development of diabetes ${ }^{32}$. For the onset of type $1 \mathrm{DM}$, NK cell activity was diverse. ${ }^{45}$ On the other hand, NK cell cytotoxicity decreased in long-standing type 1 DM group than that in the non-DM healthy group. ${ }^{33,42} 45$ Type 2 diabetes mellitus (DM) and impaired glucose tolerance (IGT) patients had also significantly lower levels of NK cell activity compared to that of the normal controls in both men and women. ${ }^{43,44,47}$ These reports prompted us to investigate the expression of pNK cell surface markers and the percentage of cytokine producing pNK cells in women with GDM. We found that the percentages of CD56 bright / CD16 ${ }^{-}$NK cells were significantly lower while CD16 ${ }^{\mathrm{dim}} / \mathrm{CD} 16^{+}$were increased in GDM women than that in normal pregnant women, suggesting that cytotoxicity of NK cells is increased in GDM women. In general, it is clarified that cytotoxicity of NK cell are decrease during normal pregnancy, ${ }^{49}$ therefore, it is suggested that increased NK cell activity shown in this study may play some 
roles in the etiology or pathophysiology of GDM progression.

In addition, we found that the percentage of $\mathrm{CD} 56^{\mathrm{bright}} / \mathrm{NKp} 46^{+} \mathrm{NK}$ cells was decreased in GDM patients. The physiological function of NKp46-positive NK cells include cytotoxicity and cytokine production. ${ }^{50}$ In type 1 DM patients with long-standing disease, NKp46 and NKp30 levels in peripheral NK cells were reduced. ${ }^{45,51}$ However, in healthy blood donors, type 2 diabetes patients also showed a profound decrease in NKp46-positive NK cells. ${ }^{29}$

Moreover, we found that the percentage of IFN- $\gamma$ producing $\mathrm{CD}^{+} 6^{+}$cells and TNF- $\alpha$ producing $\mathrm{CD}^{+} 6^{+}$cells were significantly higher in GDM women than those in non-GDM women. IFN- $\gamma$ plays important roles in the progressive loss of beta-cell mass and function during the development of both type 1 and type 2 diabetes. ${ }^{52}$ In recent-onset type- 1 diabetes patients (within one month after diagnosis of T1DM) strong IFN- $\gamma$ expression was observed in the peripheral NK cells. ${ }^{45}$ However in long-standing group (duration $>1$ year), the expression of IFN- $\gamma$ in peripheral NK cells was reduced. ${ }^{45}$ Hayashi et al. suggested that IFN- $\gamma$ could cause pancreatic islet inflammation leading to islet cell destruction. ${ }^{37} \mathrm{TNF}-\alpha$ has been implicated in the pathogenesis of insulin resistance in type $2 \mathrm{DM}^{53}$. Patients with type $2 \mathrm{DM}$ had high levels of TNF- $\alpha$ than that in the healthy volunteers and the increase in the level was dependent on the patients' degree of obesity. ${ }^{54}$ TNF- $\alpha$ has been also demonstrated to be the most significant predictor of pregnancy-induced insulin resistance. ${ }^{17}$

Interestingly, the results of this study showed that the percentage of TGF- $\beta$ producing CD56 ${ }^{+}$ cells and VEGF producing CD56 $6^{\text {bright }}$ cells were significantly lower than that in non-GDM women. TGF- $\beta$ is one of the anti-inflammatory and immunosuppressive cytokines. ${ }^{55}$ Serum TGF- $\beta$ level was shown to increase in type 2 DM with poor glycemic control (HbA1c $>7.6 \%$ ) compared to the patients with good glycemic control (HbA1c 5.5-7.6\%). ${ }^{56}$ There are significant linear relations between plasma TGF- $\beta 1$ and fasting insulin level. ${ }^{57}$ VEGF is an angiogenic protein which contributes to the angiogenesis and endothelial cell proliferation. ${ }^{58}$ Serum 
VEGF-A levels was significantly higher in uncontrolled type 2 DM group than well-controlled DM group and healthy volunteers ${ }^{59}$. Kubisz et al reported serum VEGF could be a sensitive predictor of endothelial dysfunction in type $2 \mathrm{DM}^{60}$. Subjects enrolled in this study were not overt DM and had only slight abnormality in glucose intolerance accounting for the discrepancy between previous studies and the present one. Although NK cells can produce TGF- $\beta 1$ and VEGF, it is not clear how NK cells regulate the serum cytokine levels and the present study could not clarify whether low serum levels of these cytokines were dependent on the lower cytokine producing activity of NK cells. Further studies are required to answer these questions.

In this study, we have only collected blood samples from pregnant women at 12 weeks of gestation. Further studies, which compare the difference in the function of NK cells among DM, GDM, and normal glucose tolerance or at other gestational weeks are required, however our results may contribute to explain one of the pathological mechanisms for GDM and how women with a history of GDM has the risk of developing DM.

\section{Acknowledgement}

This study was supported by JSPS KAKENHI Grant number 24592456. The authors thank

Dr. Tando T. for her support to collect blood samples. We also thank Ms. Tsushima Y. for her help in performing the FACSCanto and FACSDiva. 


\section{Reference}

1 Bulmer JN, Williams PJ, Lash GE: Immune cells in the placental bed. The International journal of developmental biology 2010;54:281-294.

2 King A, Balendran N, Wooding P, Carter NP, Loke YW: CD3- leukocytes present in the human uterus during early placentation: phenotypic and morphologic characterization of the CD56++ population. Developmental immunology 1991;1:169-190.

3 Whitelaw PF, Croy BA: Granulated lymphocytes of pregnancy. Placenta 1996;17:533-543.

4 Robson A, Harris LK, Innes BA, Lash GE, Aljunaidy MM, Aplin JD, Baker PN, Robson SC, Bulmer JN: Uterine natural killer cells initiate spiral artery remodeling in human pregnancy. FASEB journal : official publication of the Federation of American Societies for Experimental Biology 2012;26:4876-4885.

5 Hanna J, Goldman-Wohl D, Hamani Y, Avraham I, Greenfield C, Natanson-Yaron S, Prus D, Cohen-Daniel L, Arnon TI, Manaster I, Gazit R, Yutkin V, Benharroch D, Porgador A, Keshet E, Yagel S, Mandelboim O: Decidual NK cells regulate key developmental processes at the human fetal-maternal interface. Nature medicine 2006;12:1065-1074.

6 Lash GE, Robson SC, Bulmer JN: Review: Functional role of uterine natural killer (uNK) cells in human early pregnancy decidua. Placenta 2010;31 Suppl:S87-92.

7 Acar N, Ustunel I, Demir R: Uterine natural killer (uNK) cells and their missions during pregnancy: a review. Acta histochemica 2011;113:82-91.

8 Burton GJ, Jauniaux E, Watson AL: Maternal arterial connections to the placental intervillous space during the first trimester of human pregnancy: the Boyd collection revisited. American journal of obstetrics and gynecology 1999;181:718-724.

9 Caniggia I, Winter J, Lye SJ, Post M: Oxygen and placental development during the first trimester: implications for the pathophysiology of pre-eclampsia. Placenta 2000;21 Suppl A:S25-30.

10 Guibourdenche J, Fournier T, Malassine A, Evain-Brion D: Development and hormonal functions of the human placenta. Folia histochemica et cytobiologica / Polish Academy of Sciences, Polish Histochemical and Cytochemical Society 2009;47:S35-40.

11 Fukui A, Funamizu A, Yokota M, Yamada K, Nakamua R, Fukuhara R, Kimura H, Mizunuma $\mathrm{H}$ : Uterine and circulating natural killer cells and their roles in women with recurrent pregnancy loss, implantation failure and preeclampsia. Journal of reproductive immunology 2011;90:105-110.

12 Fukui A, Kwak-Kim J, Ntrivalas E, Gilman-Sachs A, Lee SK, Beaman K: Intracellular cytokine expression of peripheral blood natural killer cell subsets in women with 
recurrent spontaneous abortions and implantation failures. Fertility and sterility 2008;89:157-165.

13 Fukui A, Ntrivalas E, Fukuhara R, Fujii S, Mizunuma H, Gilman-Sachs A, Beaman K, Kwak-Kim J: Correlation between natural cytotoxicity receptors and intracellular cytokine expression of peripheral blood NK cells in women with recurrent pregnancy losses and implantation failures. American journal of reproductive immunology (New York, NY : 1989) 2009;62:371-380.

14 Fukui A, Ntrivalas E, Gilman-Sachs A, Kwak-Kim J, Lee SK, Levine R, Beaman K: Expression of natural cytotoxicity receptors and a2V-ATPase on peripheral blood NK cell subsets in women with recurrent spontaneous abortions and implantation failures. American journal of reproductive immunology (New York, NY : 1989) 2006;56:312-320.

15 Fukui A, Yokota M, Funamizu A, Nakamua R, Fukuhara R, Yamada K, Kimura H, Fukuyama A, Kamoi M, Tanaka K, Mizunuma H: Changes of NK cells in preeclampsia. American journal of reproductive immunology (New York, NY : 1989) 2012;67:278-286.

16 Ategbo JM, Grissa O, Yessoufou A, Hichami A, Dramane KL, Moutairou K, Miled A, Grissa A, Jerbi M, Tabka Z, Khan NA: Modulation of adipokines and cytokines in gestational diabetes and macrosomia. The Journal of clinical endocrinology and metabolism 2006;91:4137-4143.

$17 \mathrm{Xu}$ J, Zhao YH, Chen YP, Yuan XL, Wang J, Zhu H, Lu CM: Maternal circulating concentrations of tumor necrosis factor-alpha, leptin, and adiponectin in gestational diabetes mellitus: a systematic review and meta-analysis. TheScientificWorldJournal 2014;2014:926932.

18 Coughlan MT, Oliva K, Georgiou HM, Permezel JM, Rice GE: Glucose-induced release of tumour necrosis factor-alpha from human placental and adipose tissues in gestational diabetes mellitus. Diabetic medicine : a journal of the British Diabetic Association 2001;18:921-927.

19 Kirwan JP, Hauguel-De Mouzon S, Lepercq J, Challier JC, Huston-Presley L, Friedman JE, Kalhan SC, Catalano PM: TNF-alpha is a predictor of insulin resistance in human pregnancy. Diabetes 2002;51:2207-2213.

20 Pantham P, Aye IL, Powell TL: Inflammation in maternal obesity and gestational diabetes mellitus. Placenta 2015;36:709-715.

21 Minakami H, Maeda T, Fujii T, Hamada H, Iitsuka Y, Itakura A, Itoh H, Iwashita M, Kanagawa T, Kanai M, Kasuga Y, Kawabata M, Kobayashi K, Kotani T, Kudo Y, Makino Y, Matsubara S, Matsuda H, Miura K, Murakoshi T, Murotsuki J, Ohkuchi A, Ohno Y, Ohshiba Y, Satoh S, Sekizawa A, Sugiura M, Suzuki S, Takahashi T, Tsukahara Y, Unno N, Yoshikawa H: Guidelines for obstetrical practice in Japan: Japan Society of Obstetrics and Gynecology (JSOG) and Japan Association of Obstetricians and 
Gynecologists (JAOG) 2014 edition. The journal of obstetrics and gynaecology research 2014;40:1469-1499.

22 Metzger BE, Gabbe SG, Persson B, Buchanan TA, Catalano PA, Damm P, Dyer AR, Leiva A, Hod M, Kitzmiler JL, Lowe LP, McIntyre HD, Oats JJ, Omori Y, Schmidt MI: International association of diabetes and pregnancy study groups recommendations on the diagnosis and classification of hyperglycemia in pregnancy. Diabetes care 2010;33:676-682.

23 Van Ryswyk E, Middleton P, Shute E, Hague W, Crowther C: Women's views and knowledge regarding healthcare seeking for gestational diabetes in the postpartum period: A systematic review of qualitative/survey studies. Diabetes research and clinical practice 2015.

24 Kampmann U, Madsen LR, Skajaa GO, Iversen DS, Moeller N, Ovesen P: Gestational diabetes: A clinical update. World journal of diabetes 2015;6:1065-1072.

25 Papadopoulou A, Lynch KF, Anderberg E, Landin-Olsson M, Hansson I, Agardh CD, Lernmark A, Berntorp K: HLA-DQB1 genotypes and islet cell autoantibodies against GAD65 and IA-2 in relation to development of diabetes post partum in women with gestational diabetes mellitus. Diabetes research and clinical practice 2012;95:260-264.

26 Nilsson C, Ursing D, Torn C, Aberg A, Landin-Olsson M: Presence of GAD antibodies during gestational diabetes mellitus predicts type 1 diabetes. Diabetes care 2007;30:1968-1971.

27 Lapolla A, Betterle C, Sanzari M, Zanchetta R, Pfeifer E, Businaro A, Fagiolo U, Plebani M, Marini S, Photiou E, Fedele D: An immunological and genetic study of patients with gestational diabetes mellitus. Acta diabetologica 1996;33:139-144.

28 Lotfy M, Adeghate J, Kalasz H, Singh J, Adeghate E: Chronic complications of diabetes mellitus: A mini review. Current diabetes reviews 2015.

29 Berrou J, Fougeray S, Venot M, Chardiny V, Gautier JF, Dulphy N, Toubert A, Peraldi MN: Natural killer cell function, an important target for infection and tumor protection, is impaired in type 2 diabetes. PloS one 2013;8:e62418.

30 Burke SD, Dong H, Hazan AD, Croy BA: Aberrant endometrial features of pregnancy in diabetic NOD mice. Diabetes 2007;56:2919-2926.

31 Dotta F, Fondelli C, Falorni A: Can NK cells be a therapeutic target in human type 1 diabetes? European journal of immunology 2008;38:2961-2963.

32 Enk J, Mandelboim O: The role of natural cytotoxicity receptors in various pathologies: emphasis on type I diabetes. Frontiers in immunology 2014;5:4.

33 Fidan I, Yuksel S, Kalkanci A, Imir T, Kustimur S: Evaluation of the natural killer cytotoxicity and the levels of cytokines in rats with type I diabetes mellitus. Memorias do Instituto Oswaldo Cruz 2005;100:883-887. 
34 Flodstrom M, Maday A, Balakrishna D, Cleary MM, Yoshimura A, Sarvetnick N: Target cell defense prevents the development of diabetes after viral infection. Nature immunology 2002;3:373-382.

35 Guo H, Xu B, Gao L, Sun X, Qu X, Li X, Liu S, Feng J, Wang J, Tang Y, Yan G, Gao X, Jiang Y: High frequency of activated natural killer and natural killer T-cells in patients with new onset of type 2 diabetes mellitus. Experimental biology and medicine (Maywood, NJ) 2012;237:556-562.

36 Gur C, Porgador A, Elboim M, Gazit R, Mizrahi S, Stern-Ginossar N, Achdout H, Ghadially H, Dor Y, Nir T, Doviner V, Hershkovitz O, Mendelson M, Naparstek Y, Mandelboim O: The activating receptor NKp46 is essential for the development of type 1 diabetes. Nature immunology 2010;11:121-128.

37 Hayashi $\mathrm{T}$, Morimoto $\mathrm{M}$, Iwata $\mathrm{H}$, Onodera $\mathrm{T}$ : Interferon-gamma plays a role in pancreatic islet-cell destruction of reovirus type 2-induced diabetes-like syndrome in DBA/1 suckling mice. International journal of experimental pathology 1998;79:313-320.

38 Johansson SE, Hall H, Bjorklund J, Hoglund P: Broadly impaired NK cell function in non-obese diabetic mice is partially restored by NK cell activation in vivo and by IL-12/IL-18 in vitro. International immunology 2004;16:1-11.

39 Li M, Song LJ, Qin XY: Advances in the cellular immunological pathogenesis of type 1 diabetes. Journal of cellular and molecular medicine 2014;18:749-758.

40 Lindehammer SR, Fex M, Maziarz M, Hanson I, Marsal K, Lernmark A: Early-pregnancy cytokines in mothers to children developing multiple, persistent islet autoantibodies, type 1 diabetes, or both before 7 years of age. American journal of reproductive immunology (New York, NY : 1989) 2011;66:495-503.

41 Lo HC, Lin SC, Wang YM: The relationship among serum cytokines, chemokine, nitric oxide, and leptin in children with type 1 diabetes mellitus. Clinical biochemistry 2004;37:666-672.

42 Lorini R, Moretta A, Valtorta A, d'Annunzio G, Cortona L, Vitali L, Bozzola M, Severi F: Cytotoxic activity in children with insulin-dependent diabetes mellitus. Diabetes research and clinical practice 1994;23:37-42.

43 Matyszewski A, Czarnecka AM, Solarek W, Korzen P, Safir IJ, Kukwa W, Szczylik C: Molecular basis of carcinogenesis in diabetic patients (review). International journal of oncology 2015;46:1435-1443.

44 Piatkiewicz P, Milek T, Bernat-Karpinska M, Ohams M, Czech A, Ciostek P: The dysfunction of NK cells in patients with type 2 diabetes and colon cancer. Archivum immunologiae et therapiae experimentalis 2013;61:245-253.

45 Rodacki M, Svoren B, Butty V, Besse W, Laffel L, Benoist C, Mathis D: Altered natural 
killer cells in type 1 diabetic patients. Diabetes 2007;56:177-185.

46 Schloot NC, Hanifi-Moghaddam P, Goebel C, Shatavi SV, Flohe S, Kolb H, Rothe H: Serum IFN-gamma and IL-10 levels are associated with disease progression in non-obese diabetic mice. Diabetes/metabolism research and reviews 2002;18:64-70.

47 Zhang QL, Zang SF: Correlation of T lymphocyte subsets with blood glucose level and the first-phase insulin secretion in patients with type 2 diabetes mellitus. Zhongguo yi xие ke хие yиan хие bao Acta Academiae Medicinae Sinicae 2012;34:254-257.

48 Hotamisligil GS: Inflammation and metabolic disorders. Nature 2006;444:860-867.

49 Yamada H, Kato EH, Kobashi G, Ebina Y, Shimada S, Morikawa M, Sakuragi N, Fujimoto S: High NK cell activity in early pregnancy correlates with subsequent abortion with normal chromosomes in women with recurrent abortion. American journal of reproductive immunology (New York, NY : 1989) 2001;46:132-136.

50 Orange JS, Ballas ZK: Natural killer cells in human health and disease. Clinical immunology (Orlando, Fla) 2006;118:1-10.

51 Rodacki M, Milech A, de Oliveira JE: NK cells and type 1 diabetes. Clinical \& developmental immunology 2006;13:101-107.

52 Ibarra Urizar A, Friberg J, Christensen DP, Lund Christensen G, Billestrup N: Inflammatory Cytokines Stimulate Bone Morphogenetic Protein-2 Expression and Release from Pancreatic Beta Cells. Journal of interferon \& cytokine research : the official journal of the International Society for Interferon and Cytokine Research 2015.

53 Swaroop JJ, Rajarajeswari D, Naidu JN: Association of TNF-alpha with insulin resistance in type 2 diabetes mellitus. The Indian journal of medical research 2012;135:127-130.

54 Semenchenko I, Sharafetdinov K, Plotnikova OA, Alekseeva RI, Sentsova TB, Vorozhko IV: [Markers of immune inflammation in patients with type 2 diabetes and obesity]. Voprosy pitaniia 2013;82:46-50.

55 Ayatollahi M, Geramizadeh B, Samsami A: Transforming growth factor beta-1 influence on fetal allografts during pregnancy. Transplantation proceedings 2005;37:4603-4604.

56 Ibrahim S, Rashed L: Estimation of transforming growth factor-beta 1 as a marker of renal injury in type II diabetes mellitus. Saudi medical journal 2007;28:519-523.

57 Hosomi N, Noma T, Ohyama H, Takahashi T, Kohno M: Vascular proliferation and transforming growth factor-beta expression in pre- and early stage of diabetes mellitus in Otsuka Long-Evans Tokushima fatty rats. Atherosclerosis 2002;162:69-76.

58 Molvarec A, Ito M, Shima T, Yoneda S, Toldi G, Stenczer B, Vasarhelyi B, Rigo J, Jr., Saito S: Decreased proportion of peripheral blood vascular endothelial growth factor-expressing $\mathrm{T}$ and natural killer cells in preeclampsia. American journal of 
obstetrics and gynecology 2010;203:567.e561-568.

59 Ruszkowska-Ciastek B, Sokup A, Wernik T, Rhone P, Goralczyk K, Bielawski K, Fijalkowska A, Nowakowska A, Rhone E, Rosc D: Low-grade risk of hypercoagulable state in patients suffering from diabetes mellitus type 2. Journal of Zhejiang University Science B 2015;16:788-795.

60 Kubisz P, Chudy P, Stasko J, Galajda P, Holly P, Vysehradsky R, Mokan M: Circulating vascular endothelial growth factor in the normo- and/or microalbuminuric patients with type 2 diabetes mellitus. Acta diabetologica 2010;47:119-124. 


\section{Figure legend}

\section{Figure 1}

Representative dot plots of the expression of CD16 and natural cytotoxicity receptors (NCRs) on peripheral blood NK (CD56 $\left.{ }^{+}\right)$cells and NK cell subpopulation in GDM and non-GDM group. A gate is set on the lymphocyte. Lymphocytes are classified into $\mathrm{CD}^{+} 6^{+}$and $\mathrm{CD}^{-} 6^{-}$cells. In addition, CD56 ${ }^{+}$cells are classified into CD56 $6^{\text {bright }}$ and CD56 ${ }^{\mathrm{dim}}$. Co-expression of CD56 and CD16 or NCRs is evaluated.

\section{Figure 2}

The percentage of the expression of natural cytotoxicity receptors (NCRs) on peripheral blood NK cells and NK cell subpopulation in GDM and non-GDM group.

(A) The percentage of CD56 $6^{\mathrm{dim}} / \mathrm{CD} 16^{+} \mathrm{NK}$ cells in GDM group and non-GDM group.

(B) The percentage of CD56 $6^{\text {bright }} / \mathrm{CD}^{-} 6^{-} \mathrm{NK}$ cells in GDM group and non-GDM group.

(C) The percentage of CD56 ${ }^{\text {bright }} / \mathrm{NKp} 46^{+} \mathrm{NK}$ cells in GDM group and non-GDM group.

\section{Figure 3}

Representative dot plots of intracellular cytokine production on peripheral blood NK cells and NK cell subpopulation in GDM group and non-GDM group. A gate is set on the lymphocyte. Lymphocytes are classified into $\mathrm{CD}^{2} 6^{+}$and $\mathrm{CD}^{-} 6^{-}$cells. In addition, $\mathrm{CD}^{+} 6^{+}$cells are subdivided into CD56 $6^{\text {bright }}$ and CD56 ${ }^{\mathrm{dim}}$. The percentage of cytokines producing NK cells is evaluated.

Figure 4

The percentage of intracellular cytokine production on peripheral blood NK cells and NK cell subpopulation in GDM group and non-GDM.

(A) The percentage of IFN- $\gamma$ producing $\mathrm{CD} 56^{+}$cells in GDM group and non-GDM group. 
(B) The percentage of TNF- $\alpha$ producing $\mathrm{CD} 56^{+}$cells in GDM group and non-GDM group.

(C) The percentage of both IFN- $\gamma$ and TNF- $\alpha$ producing $\mathrm{CD}^{+} 6^{+}$cells in GDM group and non-GDM group.

(D) The percentage of TGF- $\beta$ producing $\mathrm{CD}^{+} 6^{+}$cells in GDM group and non-GDM group.

(E) The percentage of VEGF producing CD56 $6^{\text {bright }}$ cells in GDM group and non-GDM group. 


\section{Table 1 maternal characteristics, oral glucose tolerance test results and maternal and neonatal outcomes}

\begin{tabular}{cccc}
\hline & $\begin{array}{c}\text { GDM } \\
(\mathbf{n}=7)\end{array}$ & $\begin{array}{c}\text { Non-GDM } \\
(\mathbf{n}=\mathbf{2 7})\end{array}$ & P-value \\
\hline Maternal age (years) & $36.4 \pm 5.0$ & $32.4 \pm 4.4$ & NS \\
$\begin{array}{c}\text { Pre-gestational BMI (kg/m²) } \\
\text { A family history of diabetes } \\
\text { mellitus }\end{array}$ & $22.5 \pm 2.3$ & $21.6 \pm 2.8$ & NS \\
$\begin{array}{c}\text { [in first degree relationship] } \\
\text { HbA1c at diagnosis (\%) }\end{array}$ & $5.50 \pm 0.16$ & $10(37 \%)$ & NS \\
Glucose levels of 75-g OGTT & & - & \\
(mg/dL) & & & \\
Fasting glucose & $91.0 \pm 4.0$ & $85.2 \pm 4.1$ & NS \\
1-hour & $140.0 \pm 37.1$ & $122.0 \pm 22.8$ & NS \\
2-hours & $143.7 \pm 26.1$ & $119.6 \pm 26.7$ & p $<0.05$ \\
(week) & $39.2 \pm 1.2$ & $39.7 \pm 1.2$ & NS \\
Birth weight (g) & $3052.0 \pm 430.7$ & $3038.3 \pm 289.4$ & NS \\
\hline
\end{tabular}

BMI: body mass index, OGTT: oral glucose tolerace test 
Figure 1 Representative dot plots of the expression of CD16 and natural cytotoxicity receptors (NCRs) on peripheral blood NK $\left(\mathrm{CD} 56^{+}\right)$cells and NK cell subpopulation in GDM and non-GDM group
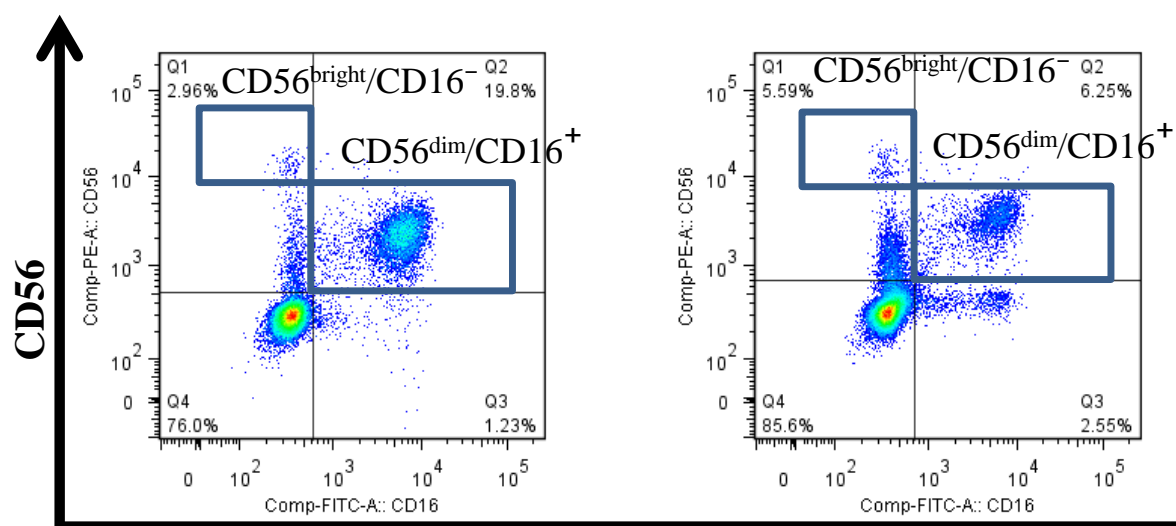

\section{CD16}
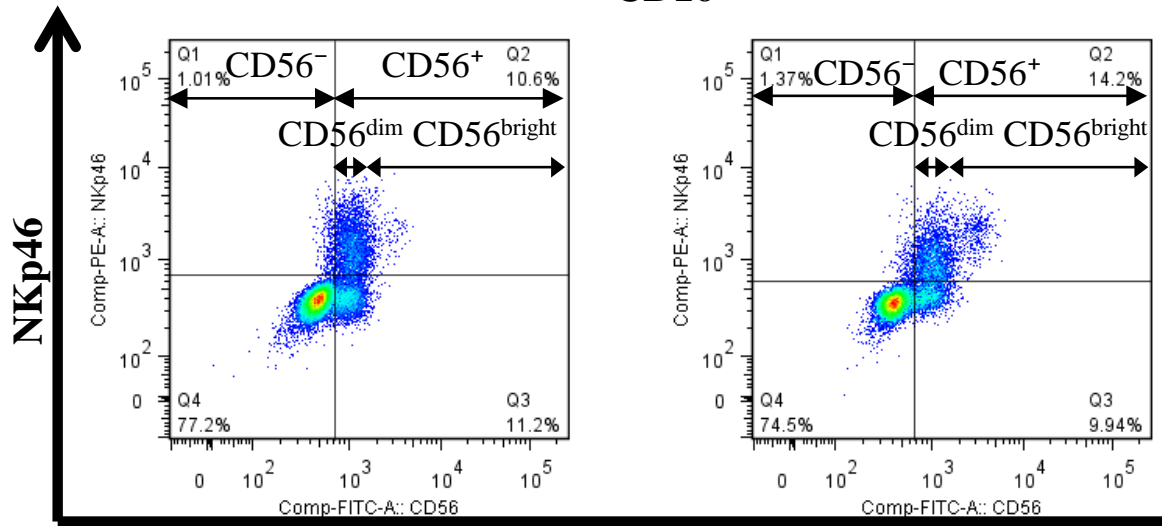

CD56
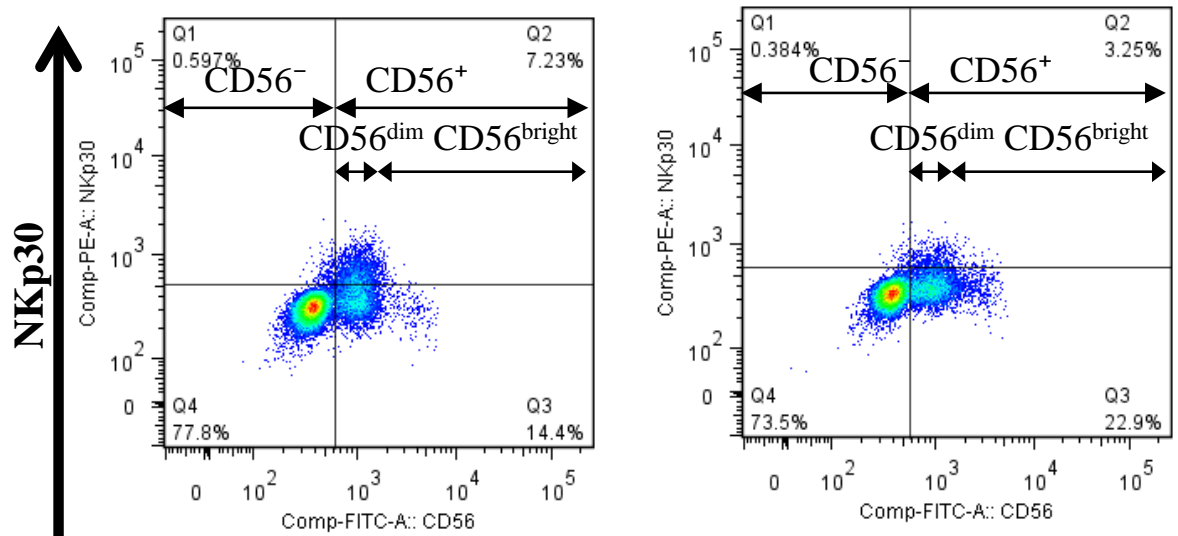
Figure 2 The percentage of the expression of natural cytotoxicity receptors (NCRs) on peripheral blood NK cells and NK cell subpopulation in GDM and non-GDM group
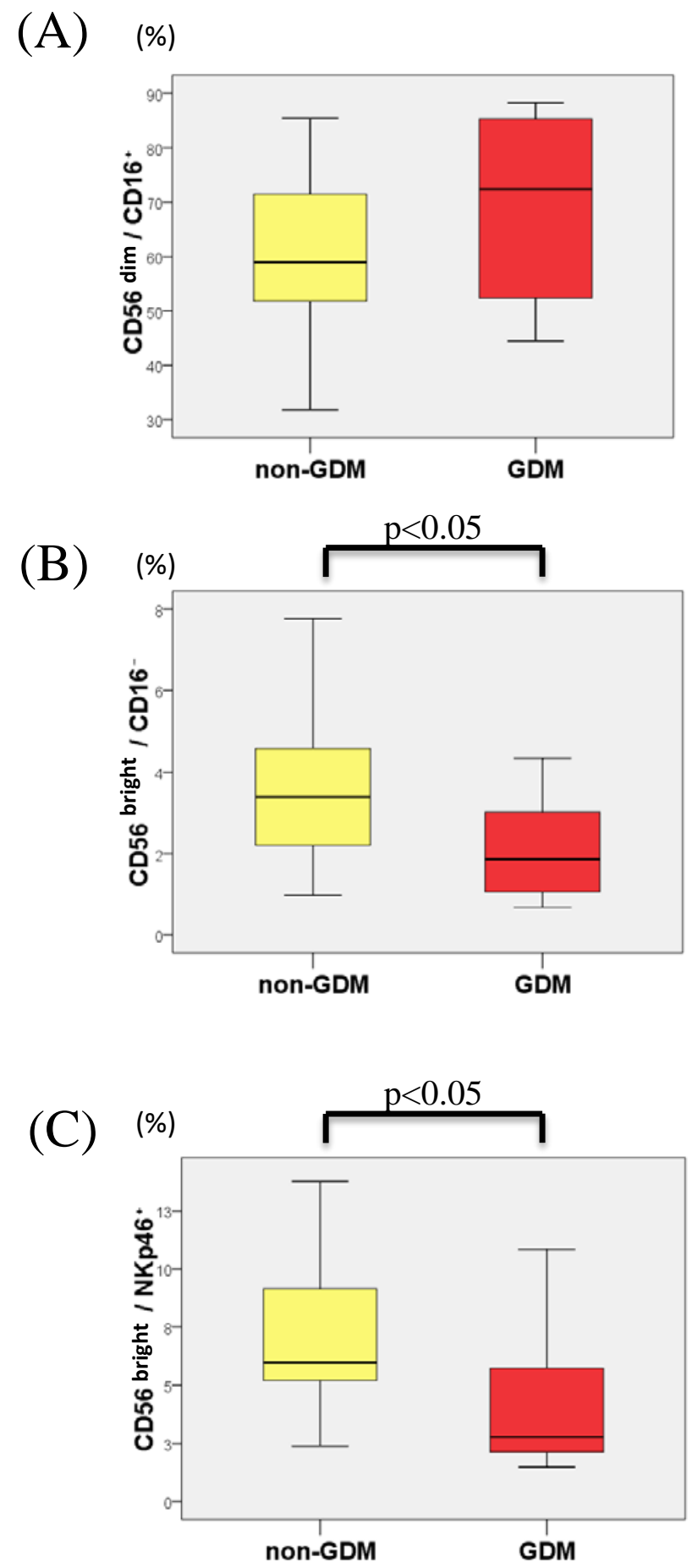
Figure 3 Representative dot plots of intracellular cytokine production on peripheral blood NK cells and NK cell subpopulation in GDM group and non-GDM group
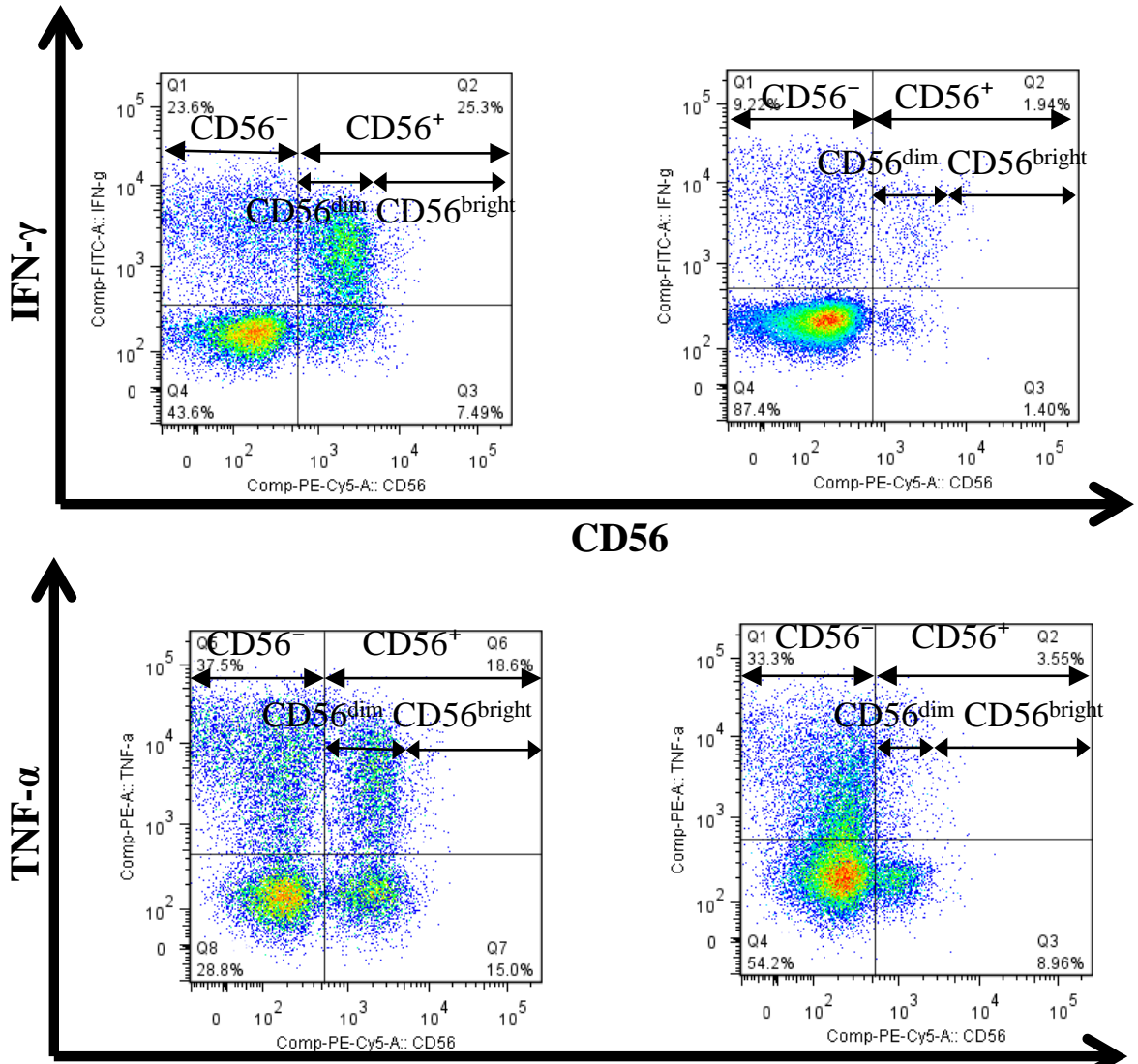

\section{CD56}

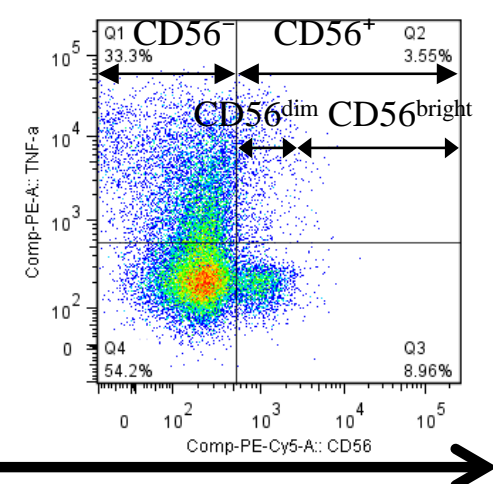

CD56
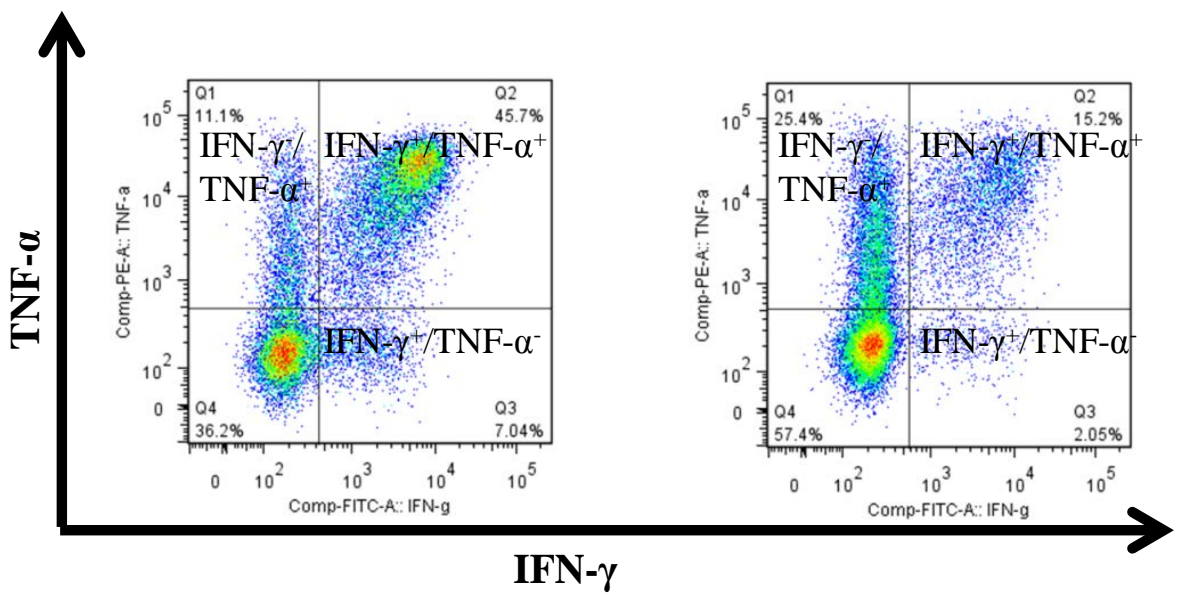

IFN- $\gamma$ 

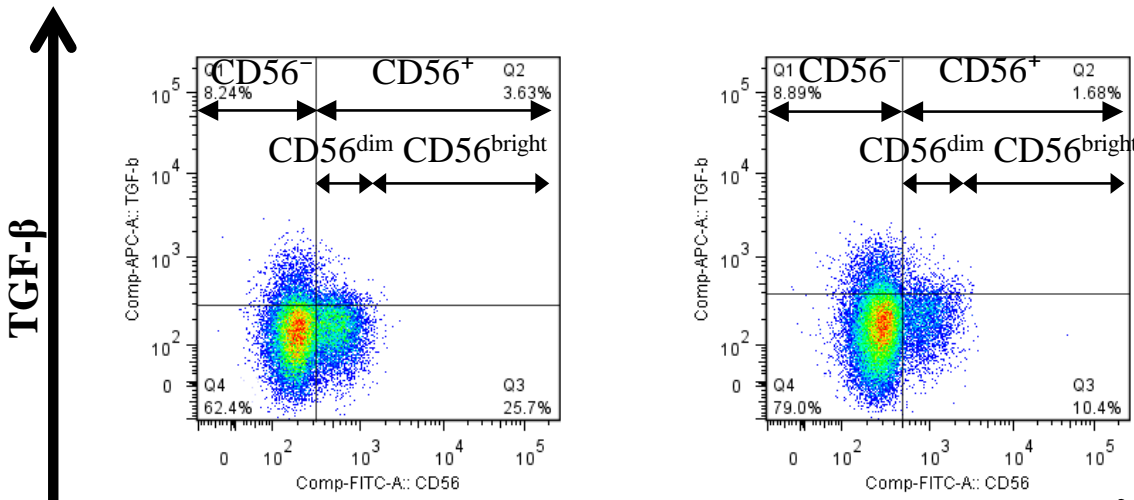

\section{CD56}

GDM

Non-GDM
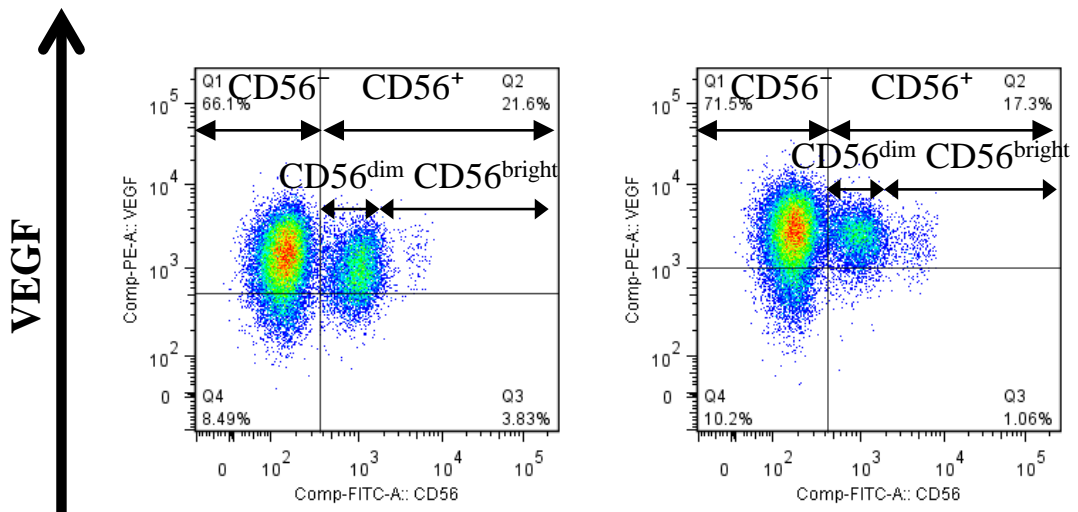

\section{CD56}

GDM

Non-GDM 
Figure 4 The percentage of intracellular cytokine production on peripheral blood NK cells and NK cell subpopulation in GDM group and non-GDM.
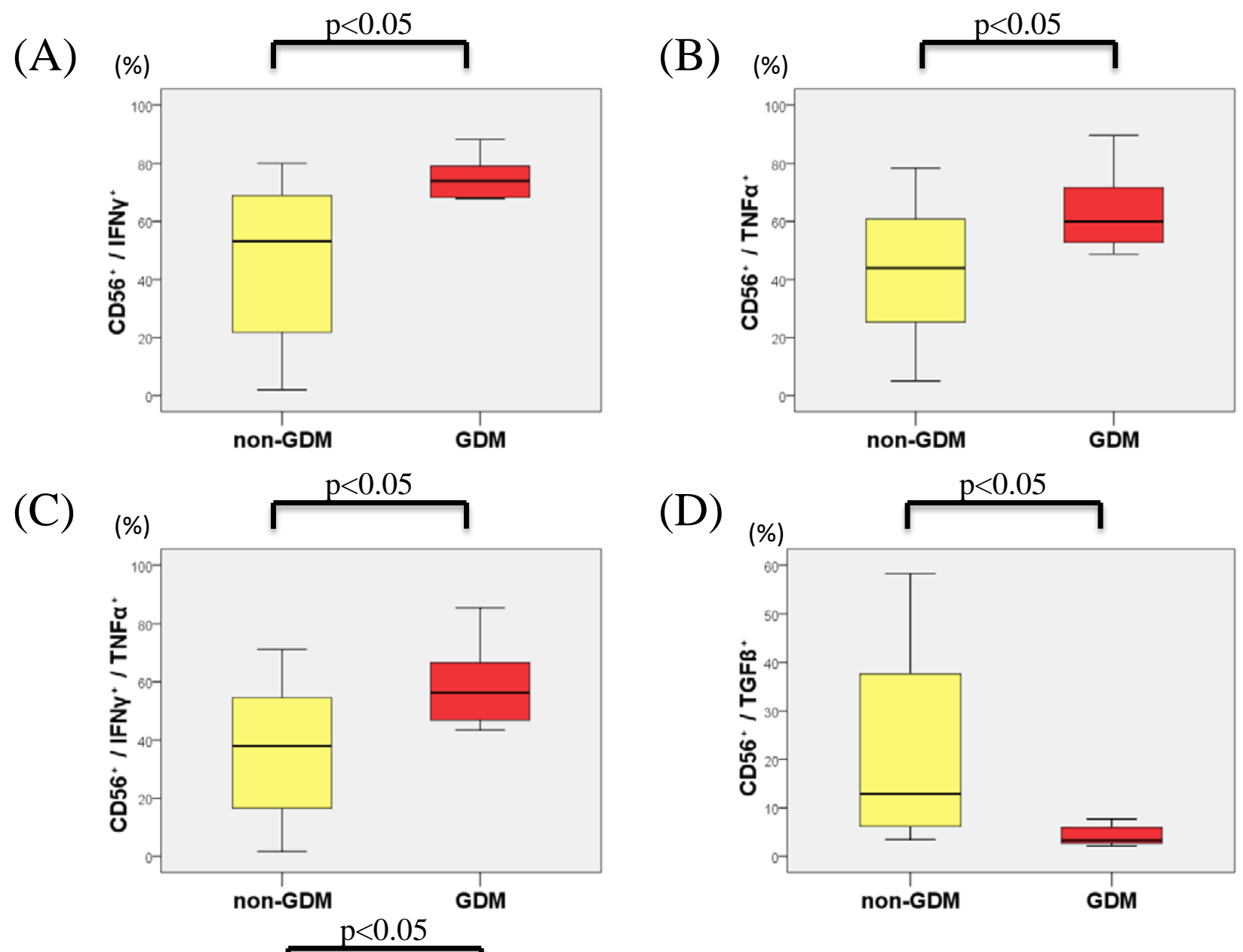

(E)

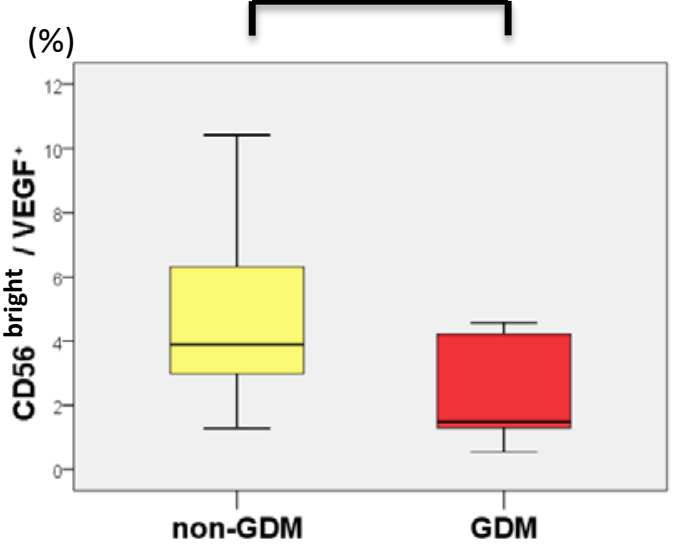

